Indonesian Journal of EFL and Linguistics

Vol. 5 No. 2, 2020

eISSN: 2503-4197, pISSN: 2527-5070

www. indonesian-efl-journal.org

\title{
Code Mixing in College Students' Presentation: A Case in an Intercultural Communication Class
}

\author{
Jauhar Helmie \\ Suryakancana University \\ e-mail: jauharhelmie@unsur.ac.id \\ Halimah \\ Suryakancana University \\ e-mail: halimah@unsur.ac.id \\ Aan Hasanah \\ Suryakancana University \\ e-mail: hasanah-aan@unsur.ac.id
}

\begin{abstract}
:
Studying the second language (L2) was happens around the world because of some reasons such as education. Studying another language can be important in intellectual human activities after studying first language (L1). However using L2 is quite hard because some of them use L2 just for some their activities, not for the whole of their activities, such as students who use English only when studying English subject only or on the contrary. Nowadays, some people use two language at the same time, which is called code mixing. The use of two codes for communication can help them to make clear their explanation from another language that they used. The purpose of this research is concerning on the use of code mixing in college students' presentation in Intercultural Communication class. Apart from that, there is an attempt to find out the language dominate in their presentation, the reasons of code mixing use in their presentation and the response of the audience about code mixing in presentation. The Method use is qualitative by using class presentation as the instrument, the writer
\end{abstract}

Indonesian Journal of EFL and Linguistics, 5(2), 2020 
Jauhar Helmie, Halimah, Aan Hasanah

collected the data of the college students' presentation, questionnaire to the audience and interview to the presenters. The research findings showed that the languages dominate in the presentation are English language and Bahasa Indonesia equally. The reasons' student in use code mixing is to make the explanation clear, and the response of the audience is $56.83 \%$ of the students give positive response in using code mixing of the presenter.

Keywords: code mixing, first language, intercultural communication, Second Language (L2)

\section{INTRODUCTION}

Sharron Heinrich, the principal at Gabrielino High School stated that being bilingual or trilingual enables students to compete economically and be a contributing member of the larger world community (Mathews, 2019). Bilingualism is a major fact of life in the world today. People who are brought up in a society where monolingualism and uniculturalism are promoted as the norm, often think of bilingualism as a rare phenomenon (Agustin, Magria, \& Setiyana, 2020). According to Crystal (1997) in (Maftoon \& Shakibafar, 2016), about two-thirds of the world's children grow up in bilingual environments. People said to be bilingual because it is able to master two or more languages in their communication (Syam, Sangkala, \& Syarif, 2018; Lowi, 2005). For example, the people as bilingual mean that besides master Sundanese as their mother tongue, and also master Indonesian as the communication language. Bilingual phenomenon can occur anywhere and anytime someone is.

Bilinguals may appear in multilingual communities where the speakers speak Multilanguage at the same time (Helmie, 2019). The continuation of bilingual or multilingual communities is deliberately possible to trigger the employing of code switching and code mixing in interaction process (Wartinah \& Wattimury, 2018).

Code switching and hereafter is called CS is the process of shifting from one language to another one in the same conversation that happens spontaneously and unconsciously. It is a generally observed phenomenon in bilingual or multilingual speakers' interactions (Sardar, MAhdi, \& Mohd, 2015). People use language to communicate each other (Halimah, Lustyantie, \& Ibrahim, 2018). When two or more people communicate with each other in speech, we can call the system of communication that they employ a code (Adhariyanty, 2015) In most cases that code will be something we may also want to call a language. CS not only occur in social community, but it also occur in classroom setting (Waris, 2012; Kustati, 2014; Nurhamidah, Fauziati, \& Supriyadi, 2018).

In the past, code-switching has been viewed negatively, even by academics. It indicates that speaker is less fluency (Sardar et al., 2015), shows incompetence, lack of credibility (Horasan, 2014) and low proficiency in target language (Narasuman, Wali, \& Sadry, 2019). Code-switching has thus been regarded as infecting, and has been 
dismissed as 'bad practice' constituting ungrammatical language usage characteristic of semi- lingual speakers without complete control of either of their languages (Grosjean 1982:147) in (Shartiely, 2016).

Muin (2011) on the other hand, arguing what had been said by Sardar et al. (2015) and Horasan (2014). On Muin (2011) perspective, SC is used by the speaker as a strategy to communicate with our interlocutor in order to keep a communication run on. Supporting Muin's opinion, Syam et al. (2018) claimed that code switching is beneficial for teachers and students to provide explanations about the subject matter to students, to get overall comprehension of conversation (Mahdi \& Almalki, 2019), to make students understand difficult and new vocabularies in the text (Obaidullah, 2016), to achieve personal motivations and communicative efficiency (Castillejo, Calizo, \& Maguddayao, 2018), and to promote relationship with students, to switch the topic, and to persuade or motivate students to be more engaged in learning English. In addition, Orynbek ( 2020) reported that in the classroom practices, participant do code switching for these reasons; to avoid misunderstanding, to help in comprehending the message delivered, to attract attention, to quote something said by others, to express loyalty to their culture, to create a sense of belonging, to persuade others, to discuss certain topics, to make the lesson more enjoyable, to crack jokes, to express themselves easily, to express personal emotions (e.g.anger, sadness, happiness, etc.), they feel more comfortable in using more than one language when speaking, it helps make learning easier for them, it helps them carry out tasks successfully, it decreases their anxiety when speaking, to help finding appropriate vocabulary, there is no equivalent word, they think using L1, and it is habitual behavior.

The deliberation about the use of L1 (first language) in EFL (English as a Foreign Language) classes has been around since the teaching as a foreign language itself. The arguments that support the use of L1 use in EFL classes claimed that L1 can be a great tool for students for L2 (English) acquisition and learning (Puspawati, 2018; Muin, 2011). Over the deliberation of the use of CS in the classroom practices, the writers concur with Maguddayao (2019) who sated that since English is the medium of instruction and code switching should be kept to an effective minimum. Language teachers are only encouraged to make adequate use of code switching in classrooms when explaining difficult concepts to students so that they will be able to actively participate in the activities and discussions. Language teachers should, in any means, use code switching to clarify concepts and not teach in the mother tongue. They should be very careful and cautious while code switching. Its use should not be made excessive as it may turn the pace of learning very slow. Besides this factor, code switching should be used only for those learners who are weak in language acquisition.

The use of CS quite often happen in EFL practices of teaching and learning over the world in which English is learned formally. It is used unconsciously by teacher or the students during conducting conversation (Wang \& $\mathrm{Wu}, 2016$ ) wrote, the study of classroom code-switching has been frequently studied over a few decade and conducted in many countries, such as in Algeria (Henni, 2017), in Bangladesh 
(Obaidullah, 2016), in China (Wang \& Wu, 2016), in Malaysia (Sardar et al., 2015), (Rahimi \& Eftekhari, 2011), in Los Angeles (Lowi, 2005) and in Ethiopia (Sime, 2019).

The use of CS also happen among Indonesian students during interacts in EFL classroom. The investigation on CS in the EFL classroom practices continue up to present era. The more recently study were conducted by Huda, Hakim, \& Mizam (2020), Tyas (2020), Patmasari \& Agussatriana (2019), Narasuman, Wali, \& Sadry (2019). It bears out that research on SC is still relevant and interesting to be carried out in that each of the study has its own uniqueness. Indonesian EFL students tend to use their L1 or L2 or the combination of the two mixes with English as the target language. This phenomena had been revealed by some researchers, such as Siregar, Bahri, \& Sanjaya (2014) investigated the use of Bataknese in EFL classroom, Agustin et al. (2020) explored the use of Minang language.

As bilinguals, Universitas Suryakancana students, specifically students majoring English Language Studies, frequently execute the code switching and code mixing by accommodating more than one language in their speaking. The enormous researches that has been done were concern on revealing the motivational reason of using CS in interaction in the classroom, the writers noted that the use CS using Sundanese is very rare investigated. That is the reason why this research is interest to be conducted in revealing switching code in college students' presentation. This research concerns on the use of English language and Bahasa Indonesia as L2 and also Sundanese as L1 among college students' presentation in Intercultural Communication class by answering the following research questions: (1) What language dominates college students' presentation?; (2) What are students' reasons of code mixing in their presentation?; and (3) How do the audience respond to the presenter use of code mixing?

\section{LITERATURE REVIEW}

\subsection{Bilingualism and Multilingualism}

In sociolinguistics the use of more than one phenomenon languages is usually dubbed bilingualism or multilingualism in a personal or social community. People who can use or speak more than one language prefer to use such codes to communicate in the individual culture or society which is called code mixing and code switching in sociolinguistics. In sociolinguistics the use of more than one language at a certain time is called code mixing and code switching. Code mixing and code swapping are phenomena that frequently occur in bilingual and multilingual societies representing group social affiliations (Wardhaugh, 2010; Moetia, KAsin, \& Fitria, 2018).

Bilingualism is a significant part of life in today's world. In a culture where monolingualism and uniculturalism are embraced as the norm, people who are brought up often think of bilingualism as an unusual phenomenon (Agustin et al, 2020). According to Crystal (1997) in (Maftoon \& Shakibafar, 2016), in bilingual environments about two-thirds of the world 's children are growing up. People said 
they were bilingual because in their conversation, they were able to master two or more languages (Syam et al., 2018; Lowi, 2005).

To clarify the term bilingual or multilingualism, Spolsky (1998:45) defines a bilingual as "a person who has some functional ability in the second language." This may vary from a limited ability in one or more domains, to very strong command of both languages. According to Bloomfield (Bloomfield, 1956) in Rahardi, 2001:13), bilingualism is a situation where a speaker can use two languages as well. Hamers (1990) in (Dewi, 2008) defines bilingualism as' the state of a linguistic culture in which two languages are in contact with the result that two codes can be used in the same interaction and a number of people are bilingual. In addition, Gumperz (1967) also mentions that bilingual people usually use their own idioms for in-group communication and the common language for their interaction and communication with outsiders. In this case, the bilinguals have a repertoire of domain-related rules of language choice (Spolsky, 1998 : 46) meaning that bilinguals are able to choose which language that he is going to use.

\subsection{Code Switching and Code Mixing}

Wardhaugh (2010) says code-switching is often very involuntary. People may not know they are moving. Consequently, as speakers of different languages converse fluently with each other, they also use words and sentences, using multiple languages in a single discourse, and moving from one language to another. Such conscious, unconscious, conversational technique is known as code-switching in linguistics. Code-mixing observed when the speaker is speaking in two languages but occurs in a single sentence. It means the speaker makes two languages utterance but these two languages occur in one language.

\subsection{Types of Code Switching}

Gumperz (1967) classify code switching into two dimensions. There are two types of code switching based on the distinction which applies to the style shifting. The first type is situational code switching. Tudini (2016) states that situational code switching occurs when the languages used change according to the situation in which the conversant find themselves: they speak one language in one situation and another in a different one. No topic change is involved. When a change topic requires a change in language used, we have metaphorical code switching. Saville-Troike (2006) define metaphorical code switching as a code switching occurring within a single situation but adding some meaning to such components.

Kustati (2014) summarized types of code switching/code mixing based on the expert into four categories; 1) Intra-Sentential Switching / Code Mixing, Mixes and switches the language occurs within a phrase, a clause or a sentence, 2) Intra-word code Mixing/switching, mixes and switches the language within the words, 3) Tagswitching/mixing, the language occurs at the phonological level (the switching of either a tag phrase or a word, or both, from language-B to language-A), 4)

Indonesian Journal of EFL and Linguistics, 5(2), 2020 
Jauhar Helmie, Halimah, Aan Hasanah

Intersentential code- mixing/switching, mixes and switches the language occurs outside a phrase, a clause or a sentence (Hoffman, 1991; Heuven \& Groot, 2017).

\section{RESEARCH METHODOLOGY}

\subsection{Participants}

The study was conducted at the eighth semester of English Education Department of a private university in West Java in the academic year of 2015/2016. The participants consisted of 38 adults aged between 18 and 25. 26 of them were female and 12 of them were male. The participants' native language is Bahasa Indonesia and they are advanced-level English students.

\subsection{Material}

An informal likert-scale questionnaire was created in light of the in-class observation by the researcher who is also the instructor of the speaking course. A 20-item informal likert scale for answering second research question, and 9-item informal likert scale for answering second research question were created by the researchers. The data was elicited through five options which ranged from 1 -Strongly disagree to 5 -Strongly agree (Dörnyei, 2003) in (Halimah, Ibrahim, \& Lustyantie, 2019). The participants were instructed to choose one of the choices reflecting their thoughts. The researchers then evaluated the results using MS Excel.

\subsection{Data Collecting Procedure}

To answer the first question, the researcher observed the participant performance by video tapped their presentation in the intercultural class. Following the observation, the writer gave questionnaire to the participants. The participants were given a 20-item likert-scale questionnaire and a 9-item likert-scale questionnaire. The items were introduced to the participants until they demonstrate an adequate understanding of the procedure and they were all tested individually. These questionnaires were given to answer the second and third questions.

\subsection{Analysis}

The researchers applied two instrument in gathering the data; observation and questionnaire. In this analysis, the writer uses a qualitative and quantitative approach. In the qualitative data, the data review process starts when the writer gathers the data from the students' presentation in the classroom. The steps in analyzing data are; presenting the data from the utterance recordings into presentation scripts, reading carefully the raw data from the conversation scripts, selecting any words, phrases, and sentences containing of code-switching, rewriting and translating the data into English, analyzing the data, explaining the types of code switching occurring in the data, describing the factors of code switching occurrences, drawing conclusion. The transcribed data were analyzed to investigate the types of code-switching use by the speaker of each group in explaining the presentation material. 
The questionnaire consisted of 20-closed-ended and 9-closed-ended questions. To analyzed the questionnaire; coding and entering the data into computer, and calculating using MS Excel. The formula used to calculate the likert scale is by finding out the total score per item and calculated the percentage of them.

\section{FINDING AND DISCUSSION}

\subsection{Code-Switching and Code-Mixing in EFL Teaching at State Institute for Islamic Studies.}

The data in this study are derived from observation conducted by video recorded of students' presentation. The observation sessions have been conducted on 6th of April 2016 and 13th of April 2016 during the 100 minutes session in undergraduate program of English at Universitas Suryakancana Cianjur, West Java. The transcribed data were analyzed to investigate the types of language use by the speaker of each group in explaining the presentation material. The summary of the use of language on the students' presentation in Intercultural Communication class is presented in the Table 1.

Table 1

The summary Language use on the students' presentation

\begin{tabular}{l} 
Types of language \\
\cline { 2 - 3 } a. Intra-Sentential Switching \\
/ Code Mixing \\
Mixes and switches the \\
language occurs within a \\
phrase, a clause or a sentence. \\
\hline b. Intra-word \\
Mixing/switching code \\
Mixes and switches the \\
language within the words \\
\hline c. Tag- switching/mixing \\
The language occurs at the \\
phonological level (the \\
switching of either a tag \\
phrase or a word, or both, \\
from language-B to language- \\
A) \\
\hline d. Intersentential code- \\
mixing/switching \\
Mixes and switches the \\
language occurs outside a \\
phrase, a clause or a sentence. \\
\hline
\end{tabular}


Jauhar Helmie, Halimah, Aan Hasanah

\subsection{Students' Motivational Reason on using Code Switching in Presentation}

To answer the second research questions, students' reported response on the questionnaire shows in Graphic 1. The questions items shows in Table 2.

Table 2

\begin{tabular}{|c|c|c|c|c|c|c|}
\hline \multicolumn{7}{|c|}{ Respond to Questionnaire (in \%) } \\
\hline No & Questions & $\begin{array}{l}\text { Strongly } \\
\text { agree }\end{array}$ & Agree & $\begin{array}{l}\text { Not } \\
\text { Sure }\end{array}$ & Disagree & $\begin{array}{l}\text { Strongly } \\
\text { Disagree }\end{array}$ \\
\hline 1 & To avoid misunderstanding & 67 & 33 & 0 & 0 & 0 \\
\hline 2 & Help to comprehend the message delivered & 33 & 67 & 0 & 0 & 0 \\
\hline 3 & to attract attention & 0 & 100 & 0 & 0 & 0 \\
\hline 4 & to quote something said by others & 0 & 100 & 0 & 0 & 0 \\
\hline 5 & to express loyalty to their culture & 100 & 0 & 0 & 0 & 0 \\
\hline 6 & to create a sense of belonging & 0 & 0 & 100 & 0 & 0 \\
\hline 7 & to persuade others & 100 & 0 & 0 & 0 & 0 \\
\hline 8 & to discuss certain topics & 100 & 0 & 0 & 0 & 0 \\
\hline 9 & to make the lesson more enjoyable. & 0 & 33 & 67 & 0 & 0 \\
\hline 10 & to crack jokes & 0 & 100 & 0 & 0 & 0 \\
\hline 11 & to express themselves easily & 67 & 33 & 0 & 0 & 0 \\
\hline 12 & $\begin{array}{l}\text { to express personal emotions (e.g.anger, } \\
\text { sadness, happiness, etc.) }\end{array}$ & 67 & 33 & 0 & 0 & 0 \\
\hline 13 & $\begin{array}{l}\text { they feel more comfortable in using more } \\
\text { than one language when speaking }\end{array}$ & 0 & 0 & 0 & 100 & 0 \\
\hline 14 & it helps make learning easier for them & 0 & 100 & 0 & 0 & 0 \\
\hline 15 & it helps them carry out tasks successfully. & 0 & 0 & 33 & 67 & 0 \\
\hline 16 & it decreases their anxiety when speaking. & 0 & 0 & 0 & 100 & 0 \\
\hline 17 & To help finding appropriate vocabulary & 0 & 100 & 0 & 0 & 0 \\
\hline 18 & There is no equivalent word & 100 & 0 & 0 & 0 & 0 \\
\hline 19 & They think using L1 & 0 & 67 & 33 & 0 & 0 \\
\hline 20 & It is habitual behavior & 0 & 67 & 33 & 0 & 0 \\
\hline
\end{tabular}

The table shows that code switching is a technique preferred by students when explaining the material of presentation to avoid misunderstanding. Out of three students reporting their agreement on code switching for this function, including $67 \%$ who strongly agreed. 33\% expressed their disagreement, 33\% students stated their strongly agree that CS help to comprehend the message delivered, 67\% stated their agreement, $100 \%$ students express their strongly agree that the use of CS can attract audience attention, $100 \%$ agree that CS is used when they quote other's statement, $100 \%$ stated that it is strongly agree the use of CS indicate that they are loyal to their culture, even though they are not sure about the idea that CS creates sense of 
belonging in classroom, on the contrary, $100 \%$ students said strongly agree that CS can persuade the audience on the topic they are presented, only $33 \%$ of them agree that CS makes the lesson more enjoyable, the rest of $67 \%$ stated not sure with that statement, $100 \%$ agree that CS can be used as a tool to crack jokes, $67 \%$ strongly agree and 33\% agree to question that CS can help them express their idea easily, $67 \%$ strongly agree and 33\% agree to question that CS can help to express personal emotions (e.g.anger, sadness, happiness, etc.), in spite of their agreement that CS gives them some benefits during presentation, $100 \%$ of them says that they do not feel comfort in using more than one language when speaking of English, 100\% agree that CS helps make learning easier for them, 33\% stated that they are not sure if CS helps them carry out tasks successfully and $67 \%$ of them disagree with this statement, $100 \%$ stated strongly agree that they use CS when they found difficulty in finding the appropriate term for there is no equivalent word in English, 67\% agree and 33\% not sure that the use of CS during presentation is contaminated by the habitual in thinking using L1.

\subsection{How do the audiences respond to the presenter use of code switching?}

The third research question was answered though students' reported responses questionnaire that is shown in Diagram 1 to Diagram 9 and the explanation accordingly. There are nine questions in this closed ended questionnaire. Those questions are adapted from the previous research finding. Those questions are presented in Table 2 .

Table 2

\section{The Matter contention of the audience respond to the presenter use of code switching}

\begin{tabular}{cl}
\hline No & Questions \\
\hline 1 & The use of CS in presentation creates a sense of belonging \\
2 & The use of CS in presentation is an evident of loyalty to their culture \\
3 & The use of CS in presentation makes the lesson more enjoyable \\
4 & The use of CS in presentation can avoid misunderstanding \\
5 & The use of CS in presentation help to comprehend the message delivered \\
6 & The use of CS in presentation shows incompetence in English \\
7 & The use of CS in presentation indicate low proficiency in target language \\
8 & Code-switching is infecting in mastering English \\
9 & Using CS in presentation shows less fluent in speaking \\
10 & It is adequate to use mother tongue when do presentation
\end{tabular}

The result of student's responses on the questionnaire about their perception toward the use of code switching by the presenter in presentation will be discussed in this section. The questionnaire was given to 35 participants as the audience in group 
Jauhar Helmie, Halimah, Aan Hasanah

presentation. The questionnaire consisted of nine questions. Being graded and analyses, it can be reported as follow.
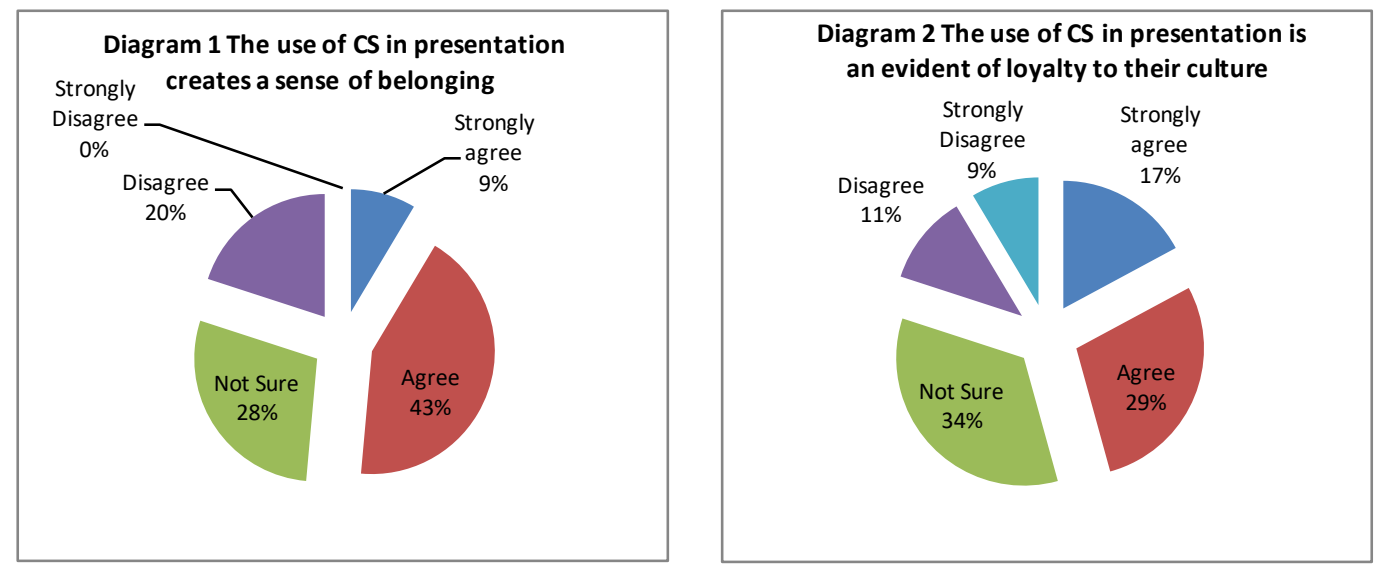

Diagram 1 shows that $9 \%$ of the participants strongly agreed and $43 \%$ agree that the use of CS in presentation creates a sense of belonging, whereas $29 \%$ of them were not sure if they code switching for this reason. $20 \%$ of them were disagree that doing CS in presentation creates a sense of belonging.

The percentages in the Diagram 2 report that student's code switching in order to express loyalty to their culture that $17 \%$ of students strongly agreed and $29 \%$ agreed on the use of code switching to express loyalty to their culture.

On the other hand, $34 \%$ not sure and $9 \%$ strongly disagreed to switch for this opinion.
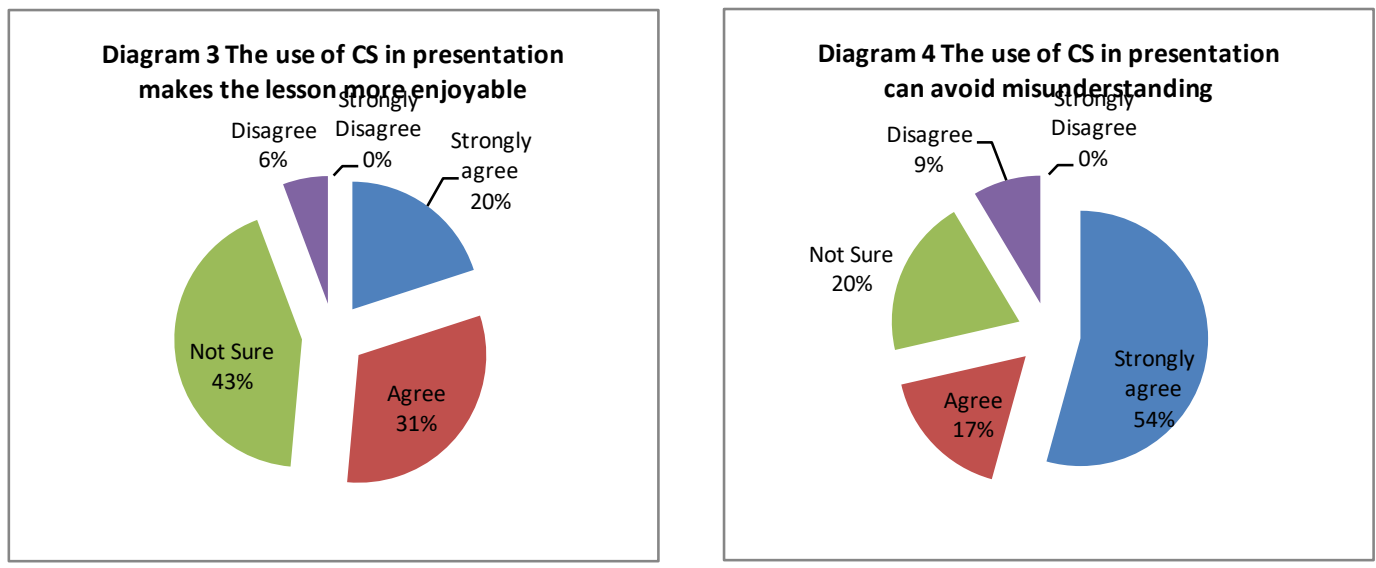

According to the percentages shown in Diagram 3, $20 \%$ students responded strongly agree, 29\% agree when the presenter use CS they more enjoy to follow the lesson, on the other hand, vast majority of student $(43 \%)$ were not sure with that condition, and only $6 \%$ acknowledged that applying CS in classroom make the lesson more enjoyable. 
Diagram 4 shows that $54 \%$ of the participants strongly agreed and $17 \%$ agree that code switching in class was to avoid misunderstanding, whereas $20 \%$ of them were not sure if they code switching for this reason, $9 \%$ of students claimed that they disagree on that statement.
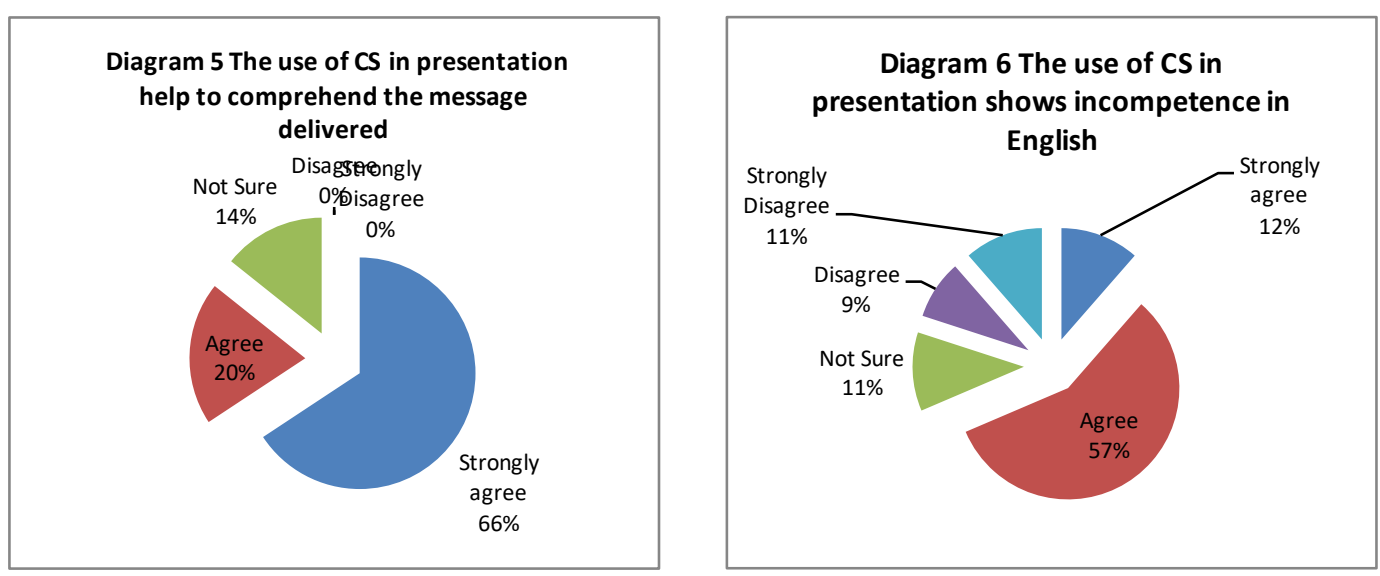

Whether students' code-switching use by the speakers helps audience to comprehend the topic being discus or not is presented in Diagram 5. Vast majority of students strongly agree (66\%), 20\% agree, 14\% were not sure, and 9\% disagree.

On the other side the students were also asked their opinion on the use of CS in the classroom. In responding to the question whether CS has potentially effect on speaker competency in English, 11\% students strongly agree, 57\% agree, $11 \%$ were not sure, 9\% disagree, and $11 \%$ students sated strongly disagree to the item.
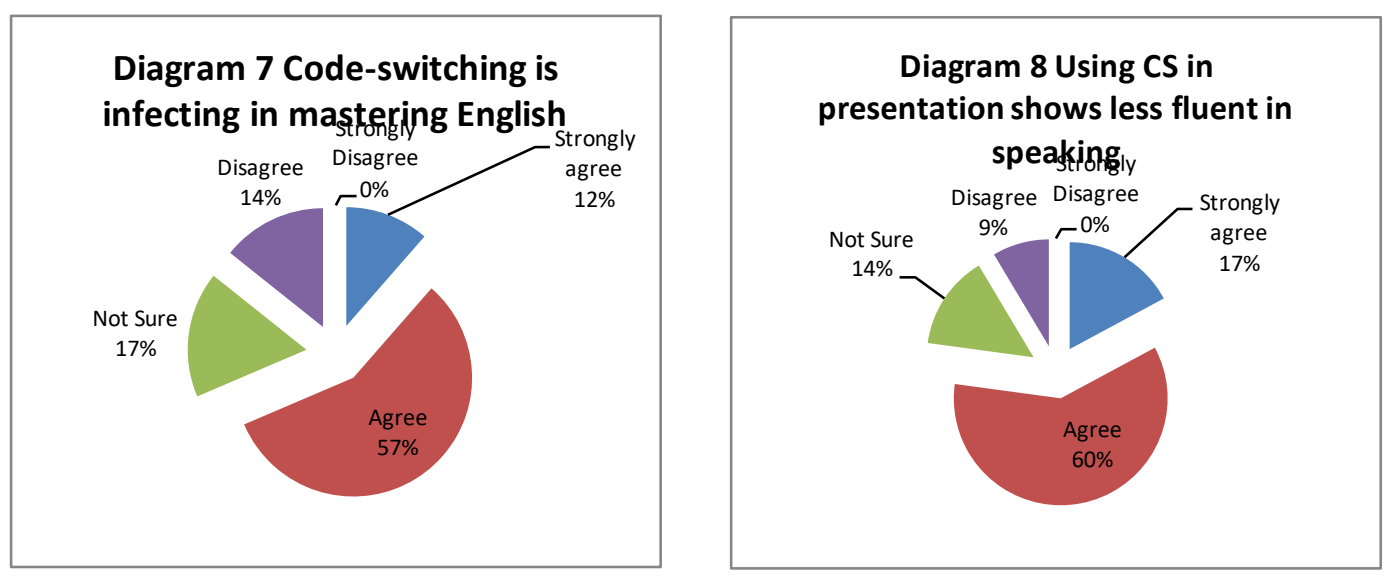

Diagram 7 confirms students' opinion on the effect of CS in mastering English. A great deal of respondents confirm that CS will effect on mastering English with 60\% 
show their agreement, $17 \%$ expressing their strong agreement, $14 \%$ were not sure, and $9 \%$ students show their disagree.

Using CS in presentation indicate that the speaker lack of speaking fluency was confirmed by the majority of respondents as show in Diagram 8, with 57\% expressing their strong agreement and $11 \%$ expressing their agreement. Very few (14\%) disagreed on switching for this technique, whereas $17 \%$ were not sure if they agree or disagree on the item.

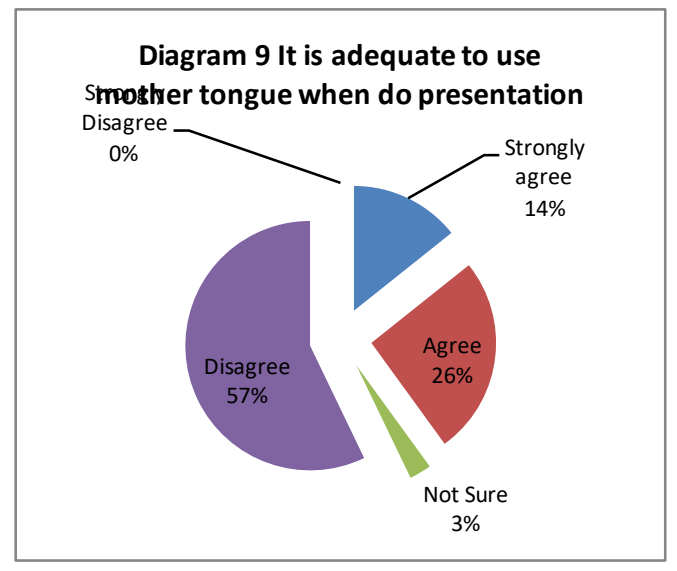

The rest of questionnaire were intended to gather students' opinion on the use of CS during presentation. On this question, $14 \%$ strongly agree that speaker could apply CS in presentation, $26 \%$ agree. Yet, $57 \%$ students disagree on that statement, and the rest $3 \%$ were not sure.

\section{DISCUSSION}

As bilingualism, ELS students potentially attach to the usage of more than one language when interact with others. In dealing with different occasions and circumstances, they possibly adjust or change the language use needed to communicate. One of the alternatives may emerge from this situation is the using of code switching and code mixing when they challenge to apply English as the necessitated language in class room interaction Based on the result of the classroom observation in Intercultural Communication by video recording, when college students' presentation, there are two language that dominates on their presentation, they are English language and Bahasa Indonesia. On the other hand, the code mixing that they used are between English language and Bahasa Indonesia.

\section{CONCLUSION}

There are some students' reasons of code mixing in their presentation. The first is the difficulties of English language when they use to explain the material in their presentation. The second one is to make the material clearly. Presentation is one of the way to share the material of the subject to the audiences by the presenters, so the explanation should be clearly to understand by the audiences. The third one is to easier 
comprehend. The average of the respond of 20 questions is $56.83 \%$. That average is positive category, that shows most of the audiens give the positive respond to the presenter use of code mixing. It is suggested to use code mixing is not always translate the material in presentation, code mixing can more useful to presentation without translate whole of the English section.

For the material in presentation should be make the common vocabulary, it means the presenters can use simple explanation without complex sentence. It can make the audience more understand without translate the English material.

Lastly, To the presenters, they are students' college in English Department, but the using of English Language is relatively small. Presentation should be one of the media to practice their English language between their first language or Bahasa Indonesia. It is hoped that the next study can give more insight about code mixing in presentation.

\section{REFERENCES}

Adhariyanty, W. (2015). Code Switching for English Language Teaching and Learning in EFL Classroom. Jurnal Ilmiah Teknologi Dan Informasia ASIA (JITIKA), 9(2), $15-17$.

Agustin, O., Magria, V., \& Setiyana, L. (2020). Code Switching as Seen in Trading ( A Sociolinguistic Studies Field Research). Journal of Foreign Language Teaching and Learning, 5(1). https://doi.org/10.18196/ftl.5147

Bloomfield, L. (1956). Language. New York: Henry and Holt Company, Inc.

Castillejo, F., Calizo, M., \& Maguddayao, R. (2018). Code Switching and Students ' Performance in English. International Journal of English and Education, 7 (October).

Dewi, I. I. (2008). Bilingualism : An Asset Or A Burden? Jurnal LINGUA CULTURA, 2(2), 129-138.

Gumperz, J. J. (1967). On the Linguistic Markers of Bilingual Communication. Journal of Social Issues: Problems of Bilingualism, 2, 48 - 57.

Halimah, Ibrahim, G. A., \& Lustyantie, N. (2019). CELLO for Better Speaker. SAR Journal, 2(3), 133-141. https://doi.org/10.18421/SAR23-08

Halimah, Lustyantie, \& Ibrahim. (2018). Students' Perception on The Implementation of Orai Application In CLL Method in Teaching Speaking. JEELS, 5(1), 1-21.

Hamers, J. F. dan M. H. A. B. (1990). Bilinguality and Bilingualism. Great Britain: Cambridge University Press.

Helmie, J. (2019). Implementation of Dialogue Journal in Teaching ( A Qualitative Case Study ), (1), 81-94.

Henni, Am. (2017). Students' Attitudes towards the Use of Code-Switching in Algerian EFL Classrooms. Revue EXPRESSIONS, 4(December), 138-148.

Heuven, V., \& Groot, D. (2017). The future of code mixing research : Integrating psycholinguistic and formal grammatical theories, 19(5), 903-906. https://doi.org/10.1017/S1366728916000390 
Jauhar Helmie, Halimah, Aan Hasanah

Hoffman, C. (1991). An Introduction to Bilingualism. New York: Longman Lingustics Library.

Horasan, S. (2014). Journal Of Language And Linguistic Studies. Journal of Language and Linguistic Studies, 10(1), 31-45.

Huda, S. T., Hakim, M., \& Mizam, M. (2020). The Realization of Code Switching : An Analysis of the Novices of Pre- Service Teachers in EFL Classroom. Pedagogy Journal of English Language Teaching, 8(1), 73-79. https://doi.org/10.32332/pedagogy.v8i1.2203

Kustati, M. (2014). An Analysis of Code-Mixing and Code-Switching in EFL Teaching of Cross Cultural Communication Context. At-Ta'lim Journal, 21(3), $174-182$.

Lowi, R. (2005). Codeswitching: An Examination of Naturally Occurring Conversation. In Proceedings of the 4th International Symposium on Bilingualism (pp. 1393-1406). Somerville: MA: Cascadilla Press.

Maftoon, P., \& Shakibafar, M. (2016). Who Is a Bilingual? Journal Of English Studies, 1(May 2011), 79-85.

Maguddayao, R. (2019). Code Switching of English Language Teachers and Students in an ESL Classroom The Asian EFL Journal Volume 21, Issue 2 . 3 Senior Editors : The Asian EFL Journal, 21(2.3), 102-122.

Mahdi, A., \& Almalki, M. S. (2019). Teachers' Perceptions towards Pedagogical Implication s of Code Switching: Saudi EFL Classroom Context in Focus. International Journal on Studies in English Language and Literature (IJSELL), 7(3), 1-9.

Mathews, J. (2019). Half of the world is bilingual. What's our problem?

Moetia, M., KAsin, U., \& Fitria, S. S. (2018). Code Mixing And Code Switching In The Classroom Interaction. English Education Journal (EEJ), 9(2), 229-242.

Muin, A. (2011). Code Switching As A Communication Strategy. Jurnal Adabiyah, Xi(2), 264-277.

Narasuman, S., Wali, A. Z., \& Sadry, Z. (2019). The Functions Of Code-Switching In Efl Classrooms. Social and Management Research Journal, 16(2), 137-151.

Nurhamidah, Fauziati, E., \& Supriyadi, S. (2018). Code-Switching in EFL Classroom : Is It Good or Bad? Journal of English Education (JEE), 3(2), 79-88.

Obaidullah, M. (2016). Code Switching in EFL Classrooms: A Bangladeshi Perspective. Theory And Practice In Language Studies, 6(5), 924-934.

Orynbek, G. (2020). Students Reasons and Attitudes for Code- Switching in Language classroom Case of Kazakhstan (Bilingual situation). International Journal of Psychosocial Rehabilitation, 24(7), 6282-6294.

Patmasari, A., \& Agussatriana. (2019). Function of Code Switching Performed by the EFL Teachers in Classroom Interaction. ELS Journal on Interdisciplinary Studies on Humanities, 2(3).

Puspawati, I. (2018). Teachers' Use of Code Switching in EFL Classroom and its Functions. Journal of Foreign Language Teaching \& Learning, 3(1), 73-74.

Rahimi, A., \& Eftekhari, M. (2011). Psycholinguistic Code Switching in Iranian 
University Classroom Context. The Journal of Language Teaching and Learning, $1,54-63$.

Sardar, S. S., MAhdi, A. A. A., \& Mohd, Y. M. S. M. (2015). Code-switching in Daily Conversations among Iraqi Students in Malaysia. Arab World English Journal (AWE), 6(3), 309-319.

Saville-Troike, M. (2006). Introducing Second Language Acquisition. Cambridge: C.U.P.: Cambridge University Press.

Shartiely, N. E. (2016). Code-switching in university classroom interaction: A case study of the University of Dar es Salaam. Stellenbosch Papers in Linguistics Plus, 49, 215-231. https://doi.org/10.5842/49-0-663

Sime, D. A. (2019). Journal of Foreign Language Education and Technology, 4(2), 2019. Journal of Foreign Language Education and Technology, 4(2), 242-268.

Siregar, M., Bahri, S., \& Sanjaya, D. (2014). Code Switching and Code Mixing in Indonesia : Study in Sociolinguistics. English Language and Literature Studies, 4(1), 77-92. https://doi.org/10.5539/ells.v4n1p77

Syam, U. K., Sangkala, I., \& Syarif, I. (2018). Code Mixing and Code Switching in the Classroom Interaction at SMA Negeri 2 Takalar. IOSR Journal Of Humanities And Social Science (IOSR-JHSS), 23(7), 95-99. https://doi.org/10.9790/08372307079599

Tudini, V. (2016). Repair and codeswitching for learning in online intercultural talk, 1-11. https://doi.org/10.1016/j.system.2016.06.011

Tyas, N. K. (2020). Code Switching in Discussion Activities in English Class. VOLES, 4(1), 11-19. https://doi.org/10.29408/veles.v4i1.1797

Wang, J., \& Wu, J. (2016). Conversation Code-switching in Class with Chinese as Foreign Language. Theory and Practice in Language Studies, 6(4), 894-905.

Wardhaugh. (2010). An Introduction to Sociolingustics (6th Ed.). UK: WileyBlackwell.

Waris, A. M. (2012). Code switching and mixing (Communication in Learning Language ). Jurnal Dakwah Tabligh, 13(1), 123-135.

Wartinah, N. N. W., \& Wattimury, C. N. (2018). Code Switching And Code Mixing In English Language Studies' Speech Community: A Sociolinguistics Approach. Berumpun Journal Volume, 1(1), 8-14. 